\title{
Community and union-led Living Wage campaigns
}

\author{
Peter Prowse \\ Sheffield Business School, Sheffield Hallam University, Sheffield, UK \\ Ana Lopes \\ Business School, Newcastle University, Newcastle upon Tyne, UK, and \\ Ray Fells \\ University of Western Australia Business School, University of Western Australia, \\ Crawley, Australia
}

\begin{abstract}
Purpose - The purpose of this paper is to demonstrate different approaches to effective campaigning in support of the Living Wage and so this paper contributes to the broader debate over the nature of the union movement's engagement with community groups in pursuit of workplace and social issues.

Design/methodology/approach - The paper presents a systematic comparison of a union-led and a community-led campaign, drawing primarily upon interview and survey data.

Findings - Though different, both campaigns met with a measure of success in improving employee pay and in increasing union membership suggesting a pragmatic approach to the building of union-community relationships.

Practical implications - The paper shows the need for campaigners to adopt a strategic approach in identifying the target for their campaign, and also the importance of shaping a persuasive argument.

Originality/value - The paper reaffirms the importance of traditional union-led campaigning alongside campaigning through engagement with community groups and so offers a broader framework for exploring the relationships between union and community groups.
\end{abstract}

Keywords Living Wage, Community campaigns, Social movement unionism, Union campaigns

Paper type Research paper

\section{Introduction}

Trade unions in Britain, as elsewhere, have faced a sustained challenge to their role and there has been extensive debate, analysis (and practical action) over the most appropriate way for the union movement to respond to these challenges (Kelly, 1998; Heery et al., 2003). At the forefront of this debate has been the notion of social movement unionism whereby unions engage with other community groups in pursuit of broader societal issues, not just workplace ones (Fairbrother and Webster, 2008; Parker, 2011). A union strategy of broader community engagement can be contrasted with more traditional forms of union activities, most particularly the pursuit of improved pay and conditions for members through industrial campaigns. Community engagement envisaged in social movement unionism and industrial campaigning are not mutually exclusive and both can take many forms.

One important aspect of social movement unionism is that it envisages engagement over a broad agenda of social and political issues. However, a significant theme of research has,

(C) Peter Prowse, Ana Lopes and Ray Fells. Published by Emerald Publishing Limited. This article is published under the Creative Commons Attribution (CC BY 4.0) licence. Anyone may reproduce, distribute, translate and create derivative works of this article (for both commercial and non-commercial purposes), subject to full attribution to the original publication and authors. The full terms of this licence may be seen at http://creativecommons.org/licences/by/4.0/legalcode.

Community and union-led Living Wage campaigns

Received 7 March 2017 Revised 22 July 2017 Accepted 28 July 2017 
ER

39,6

826

not unexpectedly, related to the nature of union-community campaigning over workplace issues, typically over issues of low pay and poor working conditions. The emergence of community-led campaigns about achieving a Living Wage (Devinatz, 2008; Holgate and Wills, 2007; Luce, 2004, 2007; Parker, 2011; Wills, 2008) is a good example of the blend of community and union campaigning about what is ultimately a workplace issue, though one with important social ramifications for the workers concerned. However, the Living Wage issue has also been pursued through more traditional union- rather than community-led campaigns raising questions about the nature of the respective campaigns. This paper offers one such comparison, between a community-led campaign over the Living Wage in London with a union-led campaign in the local government sector. Both campaigns provide insights into the importance of collective action, in whatever form, to achieve improved pay and conditions for workers in some of the most challenging sectors of the economy.

\section{Union and community campaigning}

The traditional workplace role of the unions in building membership strength and then campaigning on industrial issues has come under challenge from neo-liberal economics driving public policy. Union movements around the world have had to engage in soul searching as their memberships have declined (Fairbrother and Webster, 2008; Frege and Kelly, 2004; Lambert, 2013; Robinson, 2000). The globalisation of production processes poses further challenges for low paid workers and the unions (Miller and Williams, 2009) and while workplace organising may be regarded as necessary for union renewal (Heery, 2015) it is no guarantee of success (Hickey et al., 2010).

Unions have long sought to gain and exercise political influence to secure government policies and legislation that favours and protects employees (Webb and Webb, 1902). Although the links between the union movement and the Labour Party have become more volatile (Ludlam and Taylor, 2003) the political route to influence is still seen as a means of union renewal (Heery et al., 2003).

Besides operating in the political sphere unions have always been a social movement campaigning for issues beyond the workplace and in response to the challenges they face, they have seen the benefit of alliances with other similarly motivated organisations (Bernaciak et al., 2014, pp. 56-58; Parker, 2008). Holgate (2013) reminds us of the influence of religious teachings on the early union movement. In recent times, faith groups often find themselves campaigning on social issues that have arisen as a consequence of events in the workplace. In doing so they may find themselves campaigning alongside trade unions fighting the same issue. Other community groups can find themselves in the same situation (see e.g. Fine, 2007) and so the potential for cooperation is clear. Not only is there some commonality in the issues of concern that these various bodies are campaigning over there is also some similarity of method. The role of the lay organiser building up the solidarity and activism amongst the union membership is similar to that of those who find themselves leading community campaigns. It is often the union that has the practical experience in coalition building and organising a campaign but it is the community group that has the ability to get a crowd to rally outside an employer's premises (Luce, 2005). However, this blend of campaigning capabilities does not always prove to be sufficient; some commonality of ideology and culture as well as of goals is needed (Fine, 2007; Holgate, 2015a).

Community-led Living Wage campaigns have originated from an American-style strategy of community organising. Having a clear local focus these campaigns place great emphasis on the training of local volunteers and potential leaders "to act collectively on their own behalf" (Whitman, 2006). Training and education is seen as crucial as it is the main vehicle used to inculcate a deeper understanding about the nature, culture and ideology of broad-based organising (Holgate, 2015a). Moreover, community organisations aim to develop a base of organised people and this is achieved through relational meetings. The basic "building block" 
of community organising is the one-to-one relational conversation between community members (Tapia, 2013). Community-led Living Wage campaigns have typically involved some form of direct or public action. Classic examples include asking questions in companies' AGMs, public marches, carol singing and events such as "flashmops", where community alliance members congregated quickly in supermarkets with mopping and other cleaning instruments and called the employer to consider the Living Wage, in a song (Parsons, 2011). Such actions are usually accompanied by strategic use of the media.

We should here highlight the difference between a community-led campaign and the appeals made by unions and workers to the general public for community support for an industrial campaign they are waging. Unions have always sought - where they can get it favourable press coverage and public participation in rallies, etc. Sometimes the union and workers are more creative. Cleaners working for contractors in CBD offices in Sydney developed their own version of a "flashmop" event as part of Unite's CleanStart campaign for better pay and working conditions. To create awareness of their situation cleaners put toilets in the entrances to the plush office blocks and asked incoming workers to try to clean it in 35 seconds, the time allowed in the contract tender document. This was part of a broader union strategy to place pressure, via the occupiers of buildings on the owners and property managers rather than on the immediate employer of the cleaners (Fells, 2015).

The forms and extent of union engagement with community groups can vary ranging through an ad hoc arrangement, a simple coalition to a deeply engaged relationship (Tattershall, 2006). Ad hoc partnerships are characterised by their instrumentality and issue or event specificity. Simple partnerships have a more formal structure of decision making between union and community group but again as a sense of instrumentality about it. Where union and community groups have common interests around a broad social nature, this provides the basis for a more committed relationship and ongoing interaction with formal joint decision making and activities to strengthen the interaction between union and community members. In a sense, the actions in pursuit of the social goals are no longer "joint" actions between union and community groups (reflecting an instrumentality of interaction) but actions by a new self-sustaining entity.

Despite a potential common interest, union engagement with community groups is not inevitable as it poses a strategic challenge for unions, often at a time when low membership revenue means they are least able to respond to new challenges. When the focus of community activism is over an issue that is not related to workplace issues, such as the withdrawal of government services, or environmental concerns over a proposed business development then unions have to carefully consider devoting increasingly scarce resources to activities that are not directly related to their members' needs for improved working conditions and employment protection. When unions do seek to engage their engagement is impacted by their organisational structures that tend to be hierarchical (Symon and Crawshaw, 2009) while community activism is more organic (Tattersall, 2015). Within unions there can be differing responses with, for example, support for community engagement at the executive level and actively pursued by individual union officials, but with less engagement at from intermediate levels within the union (Simms and Holgate, 2010; Tattershall, 2006). This merely reflects pressure on union officials as they go about the business of looking after their membership. Some unions have sought to overcome the potential tensions of engagement with community groups by opening their membership to the unemployed and others who would not typically be union members (Holgate, 2015b).

\section{Low pay as a campaign issue}

Low pay remains an international issue (Laliberte, 2012) that affects individual workers, even in developed economies (Lohmann, 2009) with, for example, workers in Italy's high fashion industry found to be working for less than a Living Wage (Abiti Puliti, 2014). Institutional approaches - whether through collective bargaining or statutory minima - are not providing
Community and union-led Living Wage campaigns

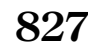


ER

39,6

828

a definitive route through which to address the issue (Garnero et al., 2015; Muller and Schulten, 2017). It is not surprising that, over time, low paid workers have looked to other ways to campaign for an improvement in their wages and in their working lives.

Every successful campaign needs a repertoire that resonates beyond the immediate actors. It is hard to argue against the notion that a worker would be paid enough to live on. This notion has been embedded in the Australian wage determination system from its inception in 1904 and, as will be shown below, has been at the heart of successful campaigning in the USA and elsewhere. The economic effects of introduction of a Living Wage are still unclear, in part because of the localised nature of campaigns (Fairris and Reich, 2005) but the moral nature of the argument being raised has provided a new dimension to the more traditional debate ("wage rise or job loss") around the minimum age and has offered a counter to the marketdriven argument of neo-liberalism. This reshaping of the argument over pay levels has, in the UK, assisted the emergence of employer support through organisations such as the Living Wage Foundation and increasing (but still seemingly reluctant) acceptance by government that the national minimum wage is not a Living Wage.

While the concept of a Living Wage is not new the modern Living Wage movement is viewed as having developed in America in the municipal government sector. In 1994, seeing full-time employees coming to their soup kitchens, Baltimoreans United in Leadership Development (a coalition of churches, trade unions and neighbourhood groups) started campaigning for a Living Wage (Luce, 2007). Their campaign spread and Lammam (2014) reported that more than 140 American municipalities have Living Wage laws. In contrast, the modern campaign for a Living Wage in the UK emerged in the commercial district of London's Canary Wharf. The East London branch (TELCO) of the community organisation Citizens UK launched the campaign in 2001 staging protest actions which led to payment of the Living Wage at prominent city banks. The campaign became national and is coordinated by the Living Wage Foundation, established in 2011 by Citizens UK. As a direct result of these campaigns, wage increases have been secured in universities, banking and financial services, healthcare, cleaning, hospitality, catering and retail (Holgate and Wills, 2007; Lopes and Hall, 2015a). A Living Wage campaign has also developed in New Zealand where the legislative framework for collective bargaining was essentially dismantled (Parker, 2011). Campaigns to achieve a Living Wage increasingly feature in developing countries such as Indonesia and Myanmar (Ford and Gillan in this journal), often as part of grass-roots political campaigns in elections (Anker and Anker, 2017).

Holgate (2015a), Tattersall (2005) and others raise questions about why unions do not engage more fully with communities and where they do, whether such engagement can be sustained. In presenting two case studies of campaigning around the same Living Wage issue, this paper offers some insights towards an answer to this question as well as some perspectives on the nature of collective campaigning.

\section{Methodology}

Both case studies have been developed through surveys, interviews and documentary analysis. The first case is of a community-led campaign at University of East London where cleaners and other workers combined together, with the support of the East London Communities Organisation (TELCO; a branch of Citizens UK) to improve their pay and working conditions. Unison also became involved. The first stage of this research took place in 2011 and it involved a survey of the cleaning staff at UEL $(n=39$, a response rate of 43 per cent). The survey focussed on the workers' motivations and experience of migration, as well as on their experience of political activity, social and civic activities and church activities. This was supplemented by a round of eight semi-structured interviews with cleaning staff at UEL (four women and four men). The interviews aimed to explore topics that emerged from the survey in greater depth. This phase of the research was also supplemented by participant observation at different stages of the 
campaign, including meetings, a complaints choir and a week-long training course delivered by Unison Hidden Workforce Unit. During a second stage, a year after the implementation of the Living Wage (2012), a second questionnaire was distributed to cleaning staff. Questions covered pay and working conditions, workloads, overtime and hours, payments and grievances. In total, 41 responses were received, a 46 per cent response rate. The same themes were further explored in a focus group and seven semi-structured interviews. All interviews were conducted face to face, either in the workplace or in the participant's home, depending on the interviewee's choice and where they felt more comfortable and safe. They lasted on average 45 minutes. The interviews were conducted in the participant's first language (Portuguese or Spanish) and subsequently translated. Interviewees were invited due to their involvement in the Living Wage campaign under study. Given the small size of the total population, these reasonably small samples were deemed representative and the interviews provided a sense of theoretical saturation. Quantitative and qualitative data were stored in password protected computers. Participant anonymity was maintained at all times. This was crucial, as cleaning staff who had taken a very active role in the campaign feared bullying and victimisation.

The second case involves the General Municipal and Boilermakers (GMB) which organised a national campaign for the Living Wage in the local government sector. Interviews were conducted in 11 local authorities (see with $7 \mathrm{GMB}$ officials (three national officers and two regional secretaries), 14 local lay officials involved in the campaigns and 13 HR directors between 2013 and 2016. All union interviewees were asked to evaluate the effectiveness of the local and national campaign and outline local campaigning effectiveness. The HR directors were all asked why they adopted the Living Wage and what obstacles prevented them from agreeing to pay immediately. The local authority areas in Table I included four London Councils, Lancashire (1), North West (2), Yorkshire (2), Wales (1) and South West (1). Information on the numbers of direct and sub-contracted employees and the estimated costs of the campaigns are in Table I.

The data from the two cases were analysed using a thematic analysis framework of organising questions derived from the literature relating to community-union campaigning, starting with the work of Tattershall (2006) who offers a typology of union-community relationships based on the depth of engagement.

\section{The community-led campaign}

The community-led case reported here is the campaign to implement the London Living Wage at a university in London's East End (UEL). (For a fuller account of the campaign,

\begin{tabular}{|c|c|c|c|c|}
\hline \multirow[b]{2}{*}{ Local authority } & \multicolumn{2}{|c|}{ Emplovees affected } & \multirow[b]{2}{*}{ Total cost $(£)$} & \\
\hline & Direct employees & Employed by subcontractor & & \\
\hline London (Hounslow) & 283 & 811 & 109,375 & \\
\hline London Barnet & 390 (341+49 casuals) & 497 & 424,106 & \\
\hline London Islington & 20 & 500 & 123,000 & \\
\hline London Barking & 286 & 497 & 106,000 & \\
\hline North West Liverpool & 600 & 600 & 52,920 & \\
\hline North West Knowsley & 900 & 0 & $1,267,200$ (est.) & \\
\hline Lancashire-Wigan & 235 & 0 & 330,880 & \\
\hline Wales Cardiff & 2,000 & 0 & $1,000,000$ & Table I. \\
\hline Yorkshire Sheffield & 257 & 3,257 & 908,000 & Outline of local \\
\hline Bradford & 2,265 & 2,000 & $1,600,000$ & councils in GMB \\
\hline \multirow[t]{2}{*}{ Exeter South West } & 56 & 0 & 25,000 & national Living \\
\hline & 13,292 & 8,319 & $5,946,481$ & Wage campaign \\
\hline
\end{tabular}
and union-led Living Wage campaigns

829
Community 
ER

39,6

830

see Lopes and Hall, 2015b.) The campaign was instigated in 2010 when, in a presentation to the students, a TELCO speaker drew attention to the fact that the sub-contracted cleaning employees were not paid the Living Wage Foundation rate. As awareness began to translate into action TELCO took the lead, and this leadership continued through the campaign. The initial campaign team included academics, students and cleaning workers. Unison's UEL branch had not recruited among the cleaning staff because the cleaners were employed by contractors, not the university. Initially the union office was unable to offer direct organising support but did find a way to do so under the umbrella of its Hidden Workforce project (www.unison.org.uk/tag/hidden-workforce/). This project was an initiative to give support to marginalised workgroups and was able to provide encouragement and practical support through workshops to help the workgroup develop and manage their campaign.

The following survey response from a male cleaning worker prior to the introduction of the Living Wage at UEL, also summarises the main issues that prompted the campaign: "Working this kind of hours - 6am to 8am - we deserve a better wage. Besides, they give us a lot of work for such few hours". Phase 1 of the campaign was kick started by a letter requesting a meeting with the university's vice-chancellor to discuss the Living Wage. The aim was to build a relationship with senior management and gain recognition, a strategy that was in part successful as it resulted in the vice-chancellor announcing that the university would sign up to be a Living Wage employer and that it would be introduced as contracts came up for re-tendering in 2011. The campaign then entered a new phase, aiming at speeding up the tendering process and implementation of the Living Wage. The main campaign tool used was the performance of a "complaints choir" in which the cleaning staff put their "complaints" in a song, such as by a 58 year old female Dominican worker: "Mucho trabajo, Y poca plata, Lots of work, Not enough money".

The campaign team produced a three-minute film containing footage of the choir practices and interviews with cleaning staff. This was posted on YouTube and caught the attention of the vice-chancellor, succeeding in its aim of focussing attention on the tendering process and getting the ethical track record of the company pushed up the agenda. (The film can be viewed at: www.youtube.com/watch?v=y-aRNW-Rst.) Supportive members of community groups attended the workgroup's activities and in doing so helped the employees feel less vulnerable to potential retaliatory action by the employer.

UEL's cleaning workers received the Living Wage in August 2011 and in 2013 the university became an accredited Living Wage employer. In the same year, UEL students and staff launched a campaign to introduce the Living Wage at London City Airport, following requests from cleaning staff for assistance. Unlike other unions, Unison's involvement with Citizens UK has been continuous and sustained (Holgate, 2015b).

\section{The union-led campaign}

Pay and conditions in the local government sector are established through negotiations in a National Joint Committee (NJC); in 2013 approximately 22 per cent of 446,300 local government workers were paid below the Living Wage Foundation rate. In October of that year the GMB' Union, Unison and Unite established a national campaign to increase the pay of their members in the local government sector to the Living Wage Foundation rate of $£ 7-45$ and a London rate of £8-80. By 2015, 175 of 375 local councils in England, Northern Ireland and Wales had adopted this rate (GMB, 2015).

The unions' campaign for an increase first took the form of a claim for an additional $£ 1$ per hour above the minimum NJC rate (i.e. to just above the Living Wage rate - a $£ 1$ increase being much easier to campaign for than one for 92 pence). However, the eventual settlement fell short of this. The GMB then campaigned at the local level, and extended the issue to the rates for sub-contractors (who were not covered by the NJC Agreement). 
The GMB has concentrated recruitment and organising members targeting catering, cleaning, environmental services and other areas of sub-contracting areas (including schools). Consequently, the union has a greater proportion of members in these occupations than Unison and Unite and so was a major driver in the local government campaign. (For further information about this campaign see Prowse and Fells, 2016a.) The local pressure was exerted through worksite meetings, keeping to contract, overtime bans and local newspaper publicity, community campaigns and lobbying local councillors (GMB, national officer and regional secretaries). The election of local councillors' local government offered unions an alternative route though Labour councillors, especially in Labour controlled or marginal where Labour had potential to secure electoral majority Council control. This was used directly by petitions, letters and lobby meetings with Labour councillors, and indirectly through the National Labour Party lobbying. The Union turned to the media where it did not have political influence. The numbers of direct and indirect employees that benefited from the union's campaign and the estimated costs to the local authorities are shown in Table I. The data show a significant flow-on to employees of contract service providers.

There is little evidence in the GMB's documentation (such as its 2013 Annual Report) or from the interviews with GMB officials and activities that the GMB actively sought the support of religious or community groups in its campaigns. Three Councils (Islington, Liverpool and Sheffield) had established "Fairness Commissions" to examine social and community issues. The Commission reports all recommended the adoption of the Living Wage by their local authority and employers as a step towards addressing these broader issues. This did not translate into ongoing involvement between community groups and the GMB as the union pursued its claims at the workplace. However, the union did draw on support when it was offered, as in the campaign at Cardiff:

It was a real political campaign but also with support from partners such as Save the Children. The joint collective agreement with GMB, Unite and Unison was praised as a beacon for the rest of Wales (GMB Cardiff Regional Officer).

All the local governments surveyed in Prowse and Fells (2016b) eventually paid the Living Wage (i.e. a rate above the NJC rate) not only for direct employees but also for sub-contractors. From the union's perspective the campaign was a success in terms of membership but also coverage as the campaign led to wage increases not only for employees of the targeted employers, the local authorities, but also for two-thirds as many again employees of private sector companies providing contracted services (Table I). Commentating on the success of two London Councils the GMB Senior organiser stated:

GMB led the discussions with Hounslow and Barking and Dagenham. Our estimates were that $70 \%$ of the membership were both part-time and low paid women with only the $£ 250$ pay increase in 2012. In 2011 we negotiated with the Local authority Cabinet and the leader of the Barking and Dagenham Council agreed the Living wage of $£ 8.30$ per hour on 31 October 2011 for directly employed council staff and non-school staff. In 2014 Barking and Dagenham Council offered a rate of $£ 9$ per hour. This rate was above the actual rate set by the Living wage Foundation. Hounslow accepted a rate of $£ 8-80$ per hour (GMB Senior Organiser).

\section{A comparison of the two cases}

The two cases of campaigning for a Living Wage show some similarities but also a number of differences that offer insights into why and how campaigns develop. The key similarity is that in terms of the primary objective, securing a Living Wage, both campaigns were successful. Where they differ is in relation to the extent to which there was union engagement with the community. With this in mind we can use Tattershall's (2006) typology as a starting point for analysis. The UEL case reported on here can be classified as a simple coalition between community and union. Tattershall (2006) recognises that such partnerships
Community and union-led Living Wage campaigns

831 
ER

39,6

832

are not necessarily equal but dominated by one party, typically the one that initiates the partnership. This is so in the UEL case where the lead was, and is, taken by the community, this being both TELCO and the workgroup. The union's role is of constructive support. Deeply engaged relationships may well be established at the organisational level - a strategic alliance to use the language of business. They could, however, grow out of a more instrumental partnership (in the same way that calculus trust can develop into identification-based trust). The ongoing relationship between TELCO, the workgroup and Unison has taken on a broader perspective in being able to assist other similar campaigns in other organisations but there is no sign of an organisational superstructure emerging that would be an indication of a more deeply engaged relationship. In contrast we can conclude that that "community engagement" or partnership does not form part of the GMB's campaign that identified all the characteristics of a traditional bargaining model. "Engagement" with the community meant creating public support for the workers but did not, for example, involve drawing community groups into the workplace campaigns and industrial action of their members. The engagement by the GMB with the community was not even ad hoc, suggesting that for completeness, we should add a "no engagement" category to Tattershall's (2006) categories of ad hoc, simple coalition and deep engagement, if only to provide insights into why unions do not engage, as well as by how much they do.

Tattershall's typology explores the nature of relationships. The focus of this paper, however, is the nature of campaigns, rather than the relationships per se. Campaigns are more focussed, in so far as they take place in a particular moment in time, and more dynamic. A number of organising questions form the basis for discussing the cases and these are summarised in Table II.

First, what were the strategic or motivating factors that gave rise to the campaign being started? According to mobilisation theory (Kelly, 1998), collective action is triggered by a sense of injustice or of a breach of shared social values (Kelly, 1998). The campaign at UEL was instigated by TELCO creating awareness of injustice (low pay) among academics and students as well as the cleaning workers themselves. Also, by making it clear that it was the vice-chancellor, senior management and the university board of governors who could remediate the problem of the cleaners' low pay, TELCO invoked "attribution", a key factor for action in mobilisation theory. (Attribution refers to placing blame on a particular agent or at least believing that a particular agent is able to remediate the problem.) Unison then became involved in an important supportive capacity. In contrast, the GMB campaign was a centrally determined strategic initiative, the joint GMB, Unison and Unite campaign. In the GMB's case responsibility for implementing the campaign was through its regional offices.

Second, with regard to community-union engagement, what was the trigger point for any engagement to occur? In the community-led case the workgroup and community organisers realised the need for some workplace expertise and turned to the local Unison branch for assistance. Naturally Unison also sought to recruit new members and was successful in this respect. As indicated above, the GMB's campaign was organised through its regional offices and union officials campaigned at individual workplaces as the opportunity arose. Each local campaign developed its own combination of industrial and political pressure. There was no explicit strategy at either national or local level to reach out to community groups as these local campaigns were waged.

Third, what is the breadth of social cohesion and identification, which according to mobilisation theory (Kelly, 1998) is a necessary factor for collective action to occur? In community campaigning group identity is created from a "broad-base" of groups and individuals with disparate views and agendas that come together around a specific issue (e.g. the Living Wage). The involvement of religious groups as an important element of support and as contributing to the success of Living Wage campaigns lead by TELCO has been discussed by Jamoul and Wills (2008). The UEL campaign received the support of faith 


\begin{tabular}{|c|c|c|c|}
\hline & Community-led campaign & Union-led campaign & Community \\
\hline $\begin{array}{l}\text { Initiation of the } \\
\text { campaign } \\
\text { Strategy/ } \\
\text { Motivation }\end{array}$ & $\begin{array}{l}\text { Unorganised workers seeking to improve their } \\
\text { working and non-work lives, and their terms } \\
\text { and conditions of employment generally }\end{array}$ & $\begin{array}{l}\text { Centrally determined } \\
\text { i) membership growth } \\
\text { ii) improved terms and conditions of } \\
\text { employment } \\
\text { iii) no broad social objective }\end{array}$ & $\begin{array}{l}\text { Living Wage } \\
\text { campaigns }\end{array}$ \\
\hline $\begin{array}{l}\text { Trigger point for } \\
\text { union } \\
\text { involvement }\end{array}$ & $\begin{array}{l}\text { Workers approach the union which sees } \\
\text { opportunity to increase its presence and } \\
\text { membership }\end{array}$ & National campaign & \\
\hline $\begin{array}{l}\text { Union's action in } \\
\text { being involved }\end{array}$ & $\begin{array}{l}\text { Some lay reps training (for immediate } \\
\text { campaigning and for ongoing organising) } \\
\text { "we'll help nurture your activity" }\end{array}$ & $\begin{array}{l}\text { Officer led } \\
\text { Support through campaign materials, } \\
\text { negotiating expertise, some lay reps } \\
\text { training (for ongoing organising) } \\
\text { "we'll take over from here" }\end{array}$ & \\
\hline $\begin{array}{l}\text { Nature of the } \\
\text { campaigning }\end{array}$ & $\begin{array}{l}\text { Waged in moral terms: } \\
\text { "greater good/right thing" arguments } \\
\text { community support in similar terms, from } \\
\text { workers' churches, etc. } \\
\text { non-industrial activities, e.g. complaints choir } \\
\text { community support for the non-industrial } \\
\text { activities }\end{array}$ & $\begin{array}{l}\text { Waged in industrial terms: } \\
\text { economic arguments, but also will use } \\
\text { moral persuasion } \\
\text { implicit/actual industrial action } \\
\text { able (in local government) to use political } \\
\text { persuasion }\end{array}$ & \\
\hline $\begin{array}{l}\text { Focus and place } \\
\text { of activity }\end{array}$ & $\begin{array}{l}\text { i) with the employer: primarily at the top level } \\
\text { (vice-chancellor, governors) } \\
\text { ii) outside the work space, i.e. to access the } \\
\text { "target" (vice-chancellor, etc.) - outside the } \\
\text { chancellery, through YouTube }\end{array}$ & $\begin{array}{l}\text { i) with the employer: primarily at the } \\
\text { bargaining table } \\
\text { ii) workplace activism } \\
\text { iii) generate a media presence }\end{array}$ & \\
\hline Outcome & $\begin{array}{l}\text { Living Wage paid, but some offsets } \\
\text { Membership increase }\end{array}$ & $\begin{array}{l}\text { Living Wage paid } \\
\text { Flow-on to contractors } \\
\text { Membership increase }\end{array}$ & \\
\hline $\begin{array}{l}\text { Ongoing union- } \\
\text { community } \\
\text { relationship }\end{array}$ & $\begin{array}{l}\text { Community groups' continued involvement } \\
\text { Ongoing union activism }\end{array}$ & & $\begin{array}{l}\text { community-led and } \\
\text { union-led Living } \\
\text { Wage campaigns }\end{array}$ \\
\hline
\end{tabular}

groups (as well as school groups) that were affiliates of TELCO. Local religious leaders supported the campaign by speaking at campaign rallies that took place on campus. Here student and university staff support and also religious community support were important. This contrasted with the 11 local authority cases surveyed where the GMB did not actively seek the engagement of community groups. Typical was the case in Sheffield where the local organiser was adept at getting favourable reports in the local press but otherwise focussed their energies on the workplace and the political arena (Prowse and Fells 2016b). This was an option not so readily available to the campaigners at UEL; the GMB was able to apply pressure to councillors, particularly during election campaigns to secure commitments that the council would pay the Living Wage.

Any campaign has to be pursued through persuasive argument - the "persuasion" coming through the nature of the proposition and coercive force that accompanies it (Chamberlain and Kuhn, 1965). How did the two groups of campaigners seek to persuade the employer? In wage negotiations the argument is typically economic - the ability of employers to pay, backed up by the threat of industrial action, the essence of which is to impose economic costs on the employer, making agreeing to the claim the 
ER

39,6

834

cost-preferable action. This was the core of the GMB's approach though, as shown above, the campaign being in the local government sector also opened the opportunity for political pressure to be exercised. The union was able to use a letter from the Leader of the Labour Party in support of the Living Wage, and also benefited the mayor of London supporting Conservative Councils to pay the Living Wage. The employers' defence - even when agreeing in principle - was the economic one of affordability. Having an economic (and political) focus does not preclude applying moral pressure on those across the bargaining table.

The UEL campaign illustrates the different way the argument can be put. We have noted that a campaign needs a compelling narrative and the notion of a Living Wage is proposition that is hard to argue against. The UEL campaign was shaped primarily in these terms, around the simple proposition that people working in an institution such as a university should be paid enough to live on. This was backed up by drawing attention to the ethical behaviour that would be expected of an institution such as a university. This shift in the central argument also requires a shift in the focus of the campaign. The cleaners did not have a seat at any bargaining table but, in any event, while the employer might agree to the moral argument it could rebut it with an economic defence. As in similar contract situations, the key decision maker is the contracting organisation, in this case the university, but to focus on the procurement office is again inviting a successful economic rebuttal. Instead there must be a strategic focus based not on economics but at senior decision makers. Hence, the effort to get the university's vice-chancellor to discuss the Living Wage and the pressure on the board of governors.

The conditional nature of the campaign's success relates to the implementation of this commitment. When the campaign entered a new phase, aiming at speeding up the tendering process and implementation of the Living Wage, the workgroup (by now many were union members) needed the evident support of their local community groups and the negotiating expertise of the union to ensure the contractor did pay Living Wage rate. The nature of the community campaigning at UEL contrasts with that of employees in the GMB-led campaign where there were protracted negotiations with both councils and contractors, coupled with industrial disputation.

How effective were the respective campaigns? The specific aim of the campaigns was to achieve the Living Wage rate for employees and by this measure both were a success. In both campaigns this success extended to sub-contracted employees, a problematic area for unions. This success was not immediate in the case of two of the councils surveyed that did not award the Living Wage until 2015. These three councils (Bradford, Cardiff and Knowsley) had not previously contracted work out and so the impact of paying the Living Wage had a more direct impact on their labour costs. In contrast, one council (Islington) benefited financially from their decision to bring sub-contracted services back in-house. Cardiff Council cited support from Labour councillors after the GMB members assisted in 2014 local elections in Cardiff and a commitment if re-elected to pay the Living Wage Foundation rate and, as indicated above, had support from other community organisations and unions.

The achievement of the Living Wage at UEL was also not clear-cut. The commitment was to achieve it through the tendering process but this process was not straightforward and so led to the second phase of the community campaign to ensure the proper outcome. However, although the workers are now paid the Living Wage there have been offsets in other terms and conditions. This, however, points to another measure by which the campaigns can be judged, namely, the extent of ongoing activism and connections with community groups. In this respect, the community-led campaign at UEL has been a success. The relationship between workers at UEL and the community groups has been maintained. Even more, UEL students and staff launched a campaign to introduce the Living Wage at London City Airport, following requests from cleaning staff for assistance. 
In both cases, the respective unions (Unison and GMB) report an increase in membership which, by their criteria, would be a measure of success. The local Unison branch at UEL was energised by the recruitment of a number of active members; this activism continued at the university through the broad coalition of staff, students and the union branch. There is less evidence of ongoing activism in the national campaign by the GMB where the picture seems to be more of local activity on a "care and maintenance" basis in anticipation of the emergence of the next workplace issue that needs to be negotiated over and a longer term campaign for $£ 10$ per hour in the future.

\section{Discussion}

A number of factors - social, economic and political - have, over the years, contributed to a situation where community groups have emerged alongside trade unions as agents for change, opening up the prospect of productive engagement between them. The two cases presented here highlight different approaches taken to pursue the same issue of the Living Wage and some broad lessons can be learned. One common feature is that in both campaigns in different ways, the persuasion strategy necessarily involves getting to a higher level in the organisation than only facing off across the bargaining table. This need for strategic engagement at executive level is particularly important when bargaining on behalf of contract employees where it is crucial to loosen up the parameters of the tendering process (i.e. more funding put into the contract) otherwise contractors have a defensible "we can't afford to pay" argument resulting in workers suffering offsets in other work conditions to pay for their own Living Wage increase. The need for this strategic persuasion is one reason, particularly in the private sector, why community engagement is important. But securing top-level commitments is not sufficient and a different form of persuasive power expertise at the bargaining table - is normally needed to ensure the benefits flow through to employees. Hence, the instrumental blending of community and union resources to ensure the success of a Living Wage campaign.

It will have been noted that the political nature of the employer in local government opened an avenue of pressure that is not possible in the private sector; the union was able to use its network of political connections to bring pressure to bear on the local councils. An area for further research would be of a union-led campaign in a private sector where the union would not have the opportunity that the GMB had to exercise some political influence to achieve their workplace objectives. From a practical perspective, the union's campaign demonstrates the need for campaigners to be strategic in identifying all possible avenue of persuasion.

In addition to highlighting the need for a strategic perspective to understand the nature of campaigning, the cases provide insights into the practical dynamics of campaigning. The different dimensions of campaign activity, as presented in Table II, provide a framework for the analysis of future campaigns and would permit international comparisons (thus overcoming one of the limitations of this UK-based study). As campaigns develop, unions and community groups bring different capabilities - organisational resources on the one hand, member mobilisation on the other (Tapia, 2013). As a result, particularly if they have been successful, campaigns can lead to partnerships. Arising out of the case studies we make two suggestions for developing Tattershall's (2006) framework of union-community relations (Table III).

The first is to include the possibility of there being no union-community relationship to help explore situations from a union perspective which has to consider whether to initiate or respond to requests from a community group. Similarly, situations may arise where the nature of the issue (particularly ones with no workplace dimensions) and where the organisational capability of the groups is high, that a community group can achieve its goals without feeling the need to reach out to the union movement.

The second proposed addition is to suggest measures of success from a community group and union perspective. This highlights the fact that each party to the relationship has
Community and union-led Living Wage campaigns 
ER

39,6

836

Table III.

Suggested extension to Tattershall's (2006) typology of unioncommunity relations additions in italics

\begin{tabular}{|c|c|c|c|c|}
\hline & None & Type of & $\begin{array}{l}\text { elationship } \\
\text { Simple coalition }\end{array}$ & Deeply engaged \\
\hline $\begin{array}{l}\text { Common } \\
\text { concern }\end{array}$ & $\begin{array}{l}\text { None } \\
\text { Union } \\
\text { pursuing its } \\
\text { own agenda }\end{array}$ & $\begin{array}{l}\text { Relationship occurs } \\
\text { around an event } \\
\text { Union or community } \\
\text { initiated }\end{array}$ & $\begin{array}{l}\text { Relationship occurs } \\
\text { around any issue } \\
\text { Union or community } \\
\text { initiated }\end{array}$ & $\begin{array}{l}\text { Issues of mutual self- } \\
\text { interest to participating } \\
\text { organisations } \\
\text { Issues framed as a broad } \\
\text { social vision }\end{array}$ \\
\hline
\end{tabular}

Structure

Union organisation and decision making

Single one off requests Formal meeting No formal or ongoing structure for decision structure to the relationship

making

Unions and community organisations involved in joint decision-making If union initiated, union structure dominated Relationship of trust and If community initiated, reciprocity limited union Bridge building across participation organisational barriers Capacity for individual/ rank and file participation

$\begin{array}{lll}\text { Place } & \begin{array}{l}\text { Workplace } \\ \text { focus }\end{array} & \text { Organised at any sca } \\ \text { Union } & \begin{array}{l}\text { Opportunistic } \\ \text { policitation of } \\ \text { community } \\ \text { support }\end{array} & \text { participation only } \\ & \end{array}$

Relationships can be at Multi-scalar capacity any level Capacity to act locally More likely in industries where capital is fixed

Union officials Unions buy into planning participate, if process community initiated, Union vision beyond junior staff participate wages and conditions Instrumental Union members active participation participants in coalition Campaign separate/ events, and in some distant from members decision making

Measure of $\quad n / a$
success for a
community
group

Achievement of event goals

Achievement of event or issue goals activism relationships and activism, reinforced through social achievement

Improved wages and Higher levels of public Union fulfilling its broader conditions for support for unions and vision of being an effective members unionism Increased membership Improved wages and agent of social change conditions for members Increased membership conditions for members

Increased membership

different objectives and a partnership will be sustained only for so long as both parties are getting benefit from it. A partnership can, therefore, be regarded as a success by one party but not the other whereas a deeply engaged partnership would be characterised not only by the parties achieving their respective goals but the engagement itself providing benefit and so becoming self-sustaining.

\section{Conclusion}

The issue of low ages is widespread and it constitutes a significant challenge to trade unions in general, and particularly in the UK. Across both developed and developing economies there seems to be a disjunction between what is set as a minimum wage and what is needed 
as a Living Wage. As labour markets and wage fixing processes become more decentralised the disjunction seems to increase. The case studies reviewed in this paper show that campaigns to address the need for workers earn a wage that they can live on can emerge from unions but also from community groups. That community groups involve themselves directly in core workplace issues such as wages is perhaps in part a reflection of the union movement's declining influence in the workplace.

Unions themselves are form of community organisations, albeit with the community being defined by the workplace, but typically they have other broader social goals extending beyond the workplace. Community groups may become established for many reasons but the quality of work-life that their members experience will impact on many of the issues the group seeks to address. So there is obvious potential for cooperation and partnerships between unions and community groups, particularly around a workplace issue that has social consequence, such as the need to achieve a Living Wage. But cooperation and partnership are not inevitable. Our analysis has highlighted the need to understand the strategic motivation of any campaign and of any decision by a union or community group to seek the involvement and support of the other but also suggests that neither union or community group can - insofar as wage campaigns are concerned - can go it alone.

\section{References}

Abiti Puliti (2014), Can You Earn a Living Wage in Fashion in Italy?, Clean Clothes Campaign, Amsterdam.

Anker, R. and Anker, M. (2017), Living Wages around the World, Edward Elgar, Cheltenham.

Bernaciak, M., Gumbrell-McCormick, R. and Hyman, R. (2014), European Trade Unionism: From Crisis to Renewal?, European Trade Union Institute, Brussels.

Chamberlain, N. and Kuhn, J. (1965), Collective Bargaining, McGraw Hill, New York, NY.

Devinatz, V.G. (2008), "Social-movement unionism and US labor's uncertain future", Journal of Collective Negotiations, Vol. 32 No. 3, pp. 203-213.

Fairbrother, P. and Webster, E. (2008), "Social movement unionism: questions and possibilities", Employee Responsibilities and Rights Journal, Vol. 20 No. 4, pp. 309-313, doi: 10.1007/s10672-0089091-1.

Fairris, D. and Reich, M. (2005), "The impacts of living wage policies: introduction to the special issue", Industrial Relations, Vol. 44 No. 1, pp. 1-13.

Fells, R. (2015), “Why isn't Australia experiencing a 'living wage' campaign?”, paper presented at Association of Industrial Relations Academics of Australia and New Zealand Annual Conference, Auckland, February.

Fine, J. (2007), "A marriage made in heaven? Mismatches and misunderstandings between worker centres and unions", British Journal of Industrial Relations, Vol. 45 No. 2, pp. 335-360.

Frege, C. and Kelly, J. (Eds) (2004), Varieties of Unionism: Strategies for Union Revitalization in a Globalizing Economy, Oxford University Press, Oxford.

Garnero, A., Kampelmann, S. and Rycx, F. (2015), "Sharp teeth or empty mouths? European institutional diversity and the sector-level minimum wage bite", British Journal of Industrial Relations, Vol. 53 No. 4, pp. 760-788.

GMB (2015), List of 184 Councils on Living Wage, available at: www.gmb.org.uk/newsroom/list-ofcouncils-on-living-wage (accessed 12 November 2015).

Heery, E. (2015), "Unions and the organising turn: reflections after 20 years of organising works", Economic and Labour Relations Review, Vol. 24 No. 4, pp. 545-560, doi: 10.1177/ 1035304615613281.

Heery, E., Kelly, J. and Waddington, J. (2003), "Union revitalization in Britain”, European Journal of Industrial Relations, Vol. 9 No. 1, pp. 79-97.
Community and union-led Living Wage campaigns 
ER

39,6

Hickey, R., Kuruvilla, S. and Lakhani, T. (2010), "No panacea for success: member activism, organising and union renewal", British Journal of Industrial Relations, Vol. 48 No. 1, pp. 53-83, doi: 10.1111/ j.1467-8543.2009.00743.x.

Holgate, J. (2013), "Faith in unions: from safe spaces to organised labour?", Capital and Class, Vol. 37 No. 2, pp. 239-262.

Holgate, J. (2015a), "An international study of trade union involvement in community organising: same model, different outcomes", British Journal of Industrial Relations, Vol. 53 No. 2, pp. 460-483.

Holgate, J. (2015b), “Community organising in the UK; a 'new' approach for trade unions?”, Economic and Industrial Democracy, Vol. 36 No. 3, pp. 431-455.

Holgate, J. and Wills, J. (2007), “Organizing labor in London”, in Turner, L. and Cornfield, D.B. (Eds), Labour in the New Urban Battlegrounds, ILR Press, Ithaca, NY, pp. 211-223.

Jamoul, L. and Wills, J. (2008), "Faith in politics”, Urban Studies, Vol. 45 No. 10, pp. 2035-2056.

Kelly, J. (1998), Rethinking Industrial Relations: Mobilization, Collectivism, and Long Waves, Routledge, London.

Laliberte, P. (2012), "Editorial”, International Journal of Labour Research, Vol. 4 No. 1, pp. 7-10.

Lambert, R. (2013), "Agent of the market, or instrument of justice? Redefining trade union identity in the era of market driven politics", Labor History, Vol. 54 No. 1, pp. 88-103.

Lammam, C. (2014), The Economic Effects of Living Wage Laws, Fraser Institute, January, Vancouver, BC, available at: www.fraserinstitute.org/sites/default/files/economic-effects-of-living-wage-laws.pdf

Lohmann, H. (2009), "Welfare states, labour market institutions and the working poor: a comparative analysis of 20 European countries", European Sociological Review, Vol. 25 No. 4, pp. 489-504.

Lopes, A. and Hall, T. (2015a), "Winning a living wage: the legacy of living wage campaigns", in Waite, L. (Ed.), Vulnerability, Exploitation and Migrants: Insecure Work in a Globalised Economy, Palgrave Macmillan, Basingstoke, pp. 230-243.

Lopes, A. and Hall, T. (2015b), "Organising migrant workers: the living wage campaign at the University of East London”, Industrial Relations Journal, Vol. 46 No. 3, pp. 208-221.

Luce, S. (2004), Fighting For A Living Wage, Cornell University Press, New York, NY.

Luce, S. (2005), "Lessons from living - wage campaigns", Work and Occupations, Vol. 32 No. 4, pp. 423-440, doi: 10.1177/0730888405279093.

Luce, S. (2007), "The US Living Wage Movement - building coalitions from the local level in a global economy", in Turner, L. and Cornfield, D.B. (Eds), Labour in the New Urban Battlegrounds, ILR Press, Ithaca, NY, pp. 21-34.

Ludlam, S. and Taylor, A. (2003), "The political representation of the labour interest in Britain", British Journal of Industrial Relations, Vol. 41 No. 4, pp. 727-749.

Miller, D. and Williams, P. (2009), "What price a living wage? Implementation issues in the quest for decent wages in the global apparel sector", Global Social Policy, Vol. 9 No. 1, pp. 99-125, doi: 10.1177/1468018108100400.

Muller, T. and Schulten, S. (2017), Minimum and Living Wages in Europe, European Trade Union Institute, Brussels.

Parker, J. (2008), "The Trades Union Congress and civil alliance building: towards social movement unionism?", Employee Relations, Vol. 30 No. 5, pp. 562-583.

Parker, J. (2011), "Reaching out for strength within? 'Social movement unionism' in a small country setting”, Industrial Relations Journal, Vol. 42 No. 4, pp. 392-403, doi: 10.1111/irj.2011.42.issue-4.

Parsons, R. (2011), "Flashmop' protest over Tesco cleaners' pay”, Evening Standard, 21 June, available at: www.standard.co.uk/news/flashmop-protest-over-tesco-cleaners-pay-6413480.html

Prowse, P. and Fells, R. (2016a), "The living wage in the UK - an analysis of the GMB campaign in local government", Labour and Industry, Vol. 26 No. 1, pp. 58-73.

Prowse, P. and Fells, R. (2016b), "The living wage: policy and practice”, Industrial Relations Journal, Vol. 47 No. 2, pp. 144-162. 
Robinson, I. (2000), "Neoliberal restricting and US unions: towards social movement unionism?", Critical Sociology, Vol. 26 Nos 1/2, pp. 109-138.

Simms, M. and Holgate, J. (2010), "Organising for what? Where is the debate on the politics of organising", Work, Employment and Society, Vol. 24 No. 1, pp. 157-168, doi: 10.1177/ 0950017010361413.

Community and union-led Living Wage campaigns

Symon, G. and Crawshaw, J. (2009), "Urban labour, voice and legitimacy: economic development and the emergence of community unionism”, Industrial Relations Journal, Vol. 40 No. 2, pp. 140-155.

Tapia, M. (2013), "Marching to different tunes: commitment and culture as mobilizing mechanisms of trade unions and community organizations", British Journal of Industrial Relations, Vol. 51 No. 4, pp. 666-88.

Tattersall, A. (2005), "There is power in coalition; a framework for assessing how and when unioncommunity coalitions are effective and enhance union power", Labour and Industry, Vol. 16 No. 2, pp. 97-112.

Tattershall, A. (2006), "Powerful community relationships and union renewal in Australia", Relations Industrielles/Industrial Relations, Vol. 61 No. 4, pp. 589-611.

Tattersall, A. (2015), "The global spread of community organizing: how 'Alinsky-style' community organizing travelled to Australia and what we learnt?", Community Development Journal, Vol. 50 No. 3, pp. 380-396.

Webb, S. and Webb, B. (1902), Industrial Democracy, Longmans, Green and Co., London.

Whitman, G. (2006), "Beyond advocacy: the history and vision of the PICO network", Social Policy, Vol. 37 No. 2, pp. 50-59.

Wills, J. (2008), "Making class politics possible: organizing contract cleaners in London", International Journal of Urban and Regional Research, Vol. 32 No. 2, pp. 305-323.

\section{Corresponding author}

Ray Fells can be contacted at: ray.fells@uwa.edu.au

For instructions on how to order reprints of this article, please visit our website: 